\title{
THE ROLE OF ITALY IN THE DEVELOPMENT OF ENERGY COOPERATION BETWEEN KAZAKHSTAN AND THE EU
}

\author{
Lyailya Nurgaliyeva \\ Kyushu University
}

\begin{abstract}
This paper focuses on the contribution of Italy to the development of energy cooperation between Kazakhstan and the EU, focusing on the specific case of the Kashagan oil field. I argue that Italy, as the largest importer of Kazakhstan's oil, can play a significant role in the diversification of energy export routes from Kazakhstan and in the introduction of new European technologies. In turn, Kazakhstan can play a prominent role in ensuring the energy security of the EU, especially after the 2014 Crimea incident. I posit that recent Italy-Kazakhstan relations shows how a mediumsized power such as Italy can be important in leading a larger block of countries into a new field of investment and development.
\end{abstract}




\section{Introduction}

The purpose of this paper is to examine the role of Italy, as the largest importer of Kazakhstan oil, in developing Kazakhstan-EU energy cooperation, and the possibility that these imports could lead to Kazakhstan diversifying its oil export routes. This study attempts to fill a gap in the existing literature, as there is not yet an in-depth study on Italy's role in the development of energy cooperation between Kazakhstan and the EU.

Although Kazakhstan researchers Kassenova Nargis (Kassenova 2011, 48-62) and Laumulin Murat (Laumulin 2000) have argued that Kazakhstan and the EU have attempted to enhance their energy dialogue, their focus was on the larger EU framework, rather than emphasizing particular actors. Specifically, Kassenova emphasized the interests, challenges, and opportunities of EUCentral Asian bilateral cooperation. She found that among all the Central Asian countries, Kazakhstan has the most advanced relationship with the EU, including political, economic, energy, and regional security spheres (Kassenova 2011, 48-59). Laumulin, on the other hand, looked at EU-Central Asia cooperation from a different angle. He noted that, since the 2000s, the European Commission has realized that Caspian resources could play an important role in world energy supplies, as well as reduce the EU's dependence on Russian energy resources. Nevertheless, there has been no strategy towards the Central Asian region because although the EU has had clear and ambitious interests, it has lacked the tools and funds to achieve them. The bulk of EU development has been limited to the countries directly on its eastern border (Laumulin 2009, 124). While the EU as a whole had not been approaching the Central Asian region, Italy had started to work actively to build bilateral basis through investments in the energy sector.

Thus, the fundamental hypothesis of this paper is that a "medium-sized power" such as Italy can be important in leading a larger block of countries into a new field of investment and development in a less-developed region. This paper will look at the development of Italian-led Kazakhstan-EU energy cooperation, focusing on the specific case of the Kashagan oil field. In order to explore my hypothesis, I will strive to answer this question: How has Italy been able to contribute to the deepening of energy cooperation between Kazakhstan and the EU?

The paper is organized as follows: Section 1 will be devoted to European energy security and Kazakhstan's hydrocarbon as a potential energy source for Europe in light of the Crimean incident of 2014. Section 2 will analyze the state of European investment in Kazakhstan energy, with a particular focus on Italy as the leading EU partner of Kazakhstan. Section 3 will discuss the Kashagan oil field, including a description of the participation of the largest Italian company, Agip (Azienda Generale Italiana Petroli), in that field. Using Kashagan as a case study, I will examine the development of Kazakhstan-Italy bilateral relations, which can stimulate the widening of energy cooperation between Kazakhstan and the EU. I will look in particular at the role of the construction of a shipyard in Kuryk port in promotion of Kashagan's oil exports via the BakuTbilisi-Ceyhan (BTC) pipeline to European markets. The last section will present Kazakhstan's goal to attract investments and new technologies.

\footnotetext{
${ }^{1}$ A medium-sized power is a power that is not a great power, but still has great influence and international recognition.
} 


\section{European Energy Security}

First I will define "energy security." Arnold Wolfers $(1952,485)$ defines security as, "a value ... that has much in common ... with power or wealth ... [it] measures the absence of threats to acquired values." John S. Duffield explains the relationship between energy and security. He argues that there was no scholarly interest in the subject before the Arab-Israeli war of 1973-1974, when Western powers were faced with the first major post-World War II threat to their energy supplies. At that time, scholars started to express their concerns and worked to define the concept of energy security. Duffield (2010, 1403) writes, "David Deese was one of the first scholars to offer a definition of energy security ... 'as a condition in which a nation perceives a high probability that it will have adequate energy supplies at affordable prices." Duffield says a similar point of view was expressed by Danel Yergin, who argued that "the objective of energy security is to assure adequate, reliable supplies of energy at reasonable prices and in ways that do not jeopardize major national values and objectives" (ibid.).

According to Duffield (2010, 1401-1402), the western countries were unsettled by two waves of oil shocks in the 1970s (the OPEC oil embargo of 1973-1974 and the Iranian revolution of 19781979), and decided to respond by cooperating on energy security. In 1974, a group of industrialized countries led by the United States created the International Energy Agency (IEA) (ibid.). The oil shocks helped shape the IEA's definition of energy security as "the uninterrupted availability of energy sources at an affordable price" (International Energy Agency 2015). The oil shocks demonstrated the energy-importing countries' vulnerability, which remains a key concern for those countries, and helped them realize "how important it is for modern societies to secure their supply of energy ... securing energy resources has become a key aspect of foreign policy making since the 1970s" (Özdamar 2010, 1415). The European Union is not an exception.

Throughout the late $20^{\text {th }}$ century the primary energy security concern was the West's dependence on Middle Eastern oil. In the last decade, however, Russia's willingness to use its energy resources as a weapon in its aggressive foreign policy has become a second key area of energy security concern.

The United States government has been concerned for several years with Europe's growing dependency on Russian energy resources. According to a 2008 United States Congressional report, the United States government had expressed its concern to Europe regarding Europe's growing dependence and the willingness of Moscow to use energy as a weapon to try to influence European foreign and economic policy. At an April 2007 US-EU summit, leaders agreed to work to cooperate on energy security and the reduction of dependence on Russia, and yet, some EU member states continued to pursue long-term agreements with Russian firms (Belkin 2008, 2). The 2014 Crimean incident, however, changed the situation significantly.

Russia's seizure of Crimea in 2014 and the resulting US and EU sanctions against Russia have pressed the European Union to much more seriously search for ways to decrease its dependence on Russian energy supplies. Richard Weitz (2014) notes that

The situation in the EU on energy security needs to be solved. On May 28, 2014, the European Commission released its comprehensive energy security strategy, according to which the long-term objective is to reduce 
the EU's reliance on vulnerable foreign energy supplies, especially from Russia ... One of Europe's core challenges is that its energy demand will rise by an estimated 27 percent by 2030, while EU domestic energy production is falling. EU members rely on external sources for $88 \%$ of their crude oil and $66 \%$ of their natural gas consumption."

The EU has traditionally not had a unified energy policy, with the exception of a package of energy reforms aimed at harmonizing member states' energy markets. To enhance energy security, the EU commission is considering ways to deal with the disruption of gas supplies by diversifying energy supplies and transport routes, particularly developing and improving routes that would bring energy supplies into Central Asia without going through Russia (Weitz 2014). One way is to increase the energy supply being imported from Kazakhstan.

\section{Kazakhstan hydrocarbon as a potential energy source for Europe}

Kazakhstan's hydrocarbon resources have the potential to help alleviate Europe's energy security concerns. Kazakhstan is a major oil producer, with potentially vast untapped hydrocarbon reserves. The estimated total liquid production in 2013 was 1.64 million barrels per day (bbl/d), which, while significant, is still far below Saudi Arabia's total 2013 oil production of 11.591 million barrels per day (US Energy Information Administration 2013b). The main oil reserves of Kazakhstan are concentrated in and around the Caspian Sea, a region that ranks second in the world in the presence of undeveloped oil and gas reserves. These data were presented at the Third International Oil and Gas Conference, Development of the Caspian shelf, which was held on June 20-21, 2013. Aset Magauov, the General Director of the national energy company KAZENERGY, noted that "the potential of the Kazakhstan sector is huge, and in the future, hydrocarbon production on the sea will reach volumes of oil extracted on Kazakhstan's land. Today is the start of a rapidly growing energy market" (Kulmagambetov 2013; author's translation). The significance of the Caspian region in the world oil and gas market was confirmed by IEA Deputy Director Richard Johnson at this conference. He said that "[t]he presence and the successful development of hydrocarbon resources of the Caspian Sea is of great importance not only for the economic prosperity of all Caspian bordering countries, but also for the global energy balance" (Johnson quoted in Konyrova 2013; author's translation). For comparison, the data on oil and gas production in the countries of the Caspian region are presented in Table 1. While Russia and Iran are currently far ahead in proved oil and gas reserves in the region, Kazakhstan and Turkmenistan have the potential of outstripping both of those countries.

The 2011-2015 strategic plan of the Ministry of Oil and Gas of the Republic of Kazakhstan, approved by Government Decree on February 14, 2011, assessed the overall recoverable hydrocarbon resources. According to this document, the Kazakhstan sector of the Caspian Sea has almost half of the oil reserves of the entire country (Egemen Kazakhstan 2011). Kazakhstan's estimated total petroleum production was 1.70 million barrels per day in 2014 (US Energy Information Administration 2015). As noted in this document, there are 172 oil and 42 gas condensate fields in the republic, and $62 \%$ of Kazakh territory lies over these fields. 
Table 1: Proven and prospective oil and gas reserves in the Caspian region

\begin{tabular}{|l|l|l|l|l|}
\hline Country & $\begin{array}{l}\text { Proven oil reserve, } \\
\text { billions of Barrels }\end{array}$ & $\begin{array}{l}\text { Prospective oil } \\
\text { reserve, }{ }^{3} \text { billions of } \\
\text { Barrels }\end{array}$ & $\begin{array}{l}\text { Proven gas reserves, } \\
\text { trillions of cubic feet }\end{array}$ & $\begin{array}{l}\text { Prospective gas reserves, } \\
\text { trillions of cubic feet }\end{array}$ \\
\hline Azerbaijan & 7 & 32 & 30 & 35 \\
\hline Iran & 89.7 & 15 & 812.3 & 11 \\
\hline Kazakhstan & 8 & 92 & 65 & 88 \\
\hline Russia & 48.6 & 14 & 1680 & no data \\
\hline Turkmenistan & 0.5 & 80 & 101 & 159 \\
\hline Total & 153.8 & 233 & 2688.3 & 293 \\
\hline
\end{tabular}

Source: British Petroleum, BP Statistical Review of World Energy, 2002 (Ayvazyan 2013)

The main reserves are concentrated in the 15 largest fields, the most prominent of which are Tengiz, Kashagan, and Karachaganak. Given the importance of the Caspian region, President Nazarbayev's Decree of May 16, 2003 (No. 1095) was approved as the State Program of Development of the Kazakhstan Sector of the Caspian Sea (Ukaz 2003). This document defines the strategy of using energy resources in Kazakhstan, and a large role is given to the Caspian region due to the increase in oil demand in Europe (ibid.). In order to meet the needs of both external and internal markets, Kazakhstan had planned to increase its oil production. In the 2000s, crude oil exports saw steady annual increases (Musabekova 2010).

Just as energy-importing countries value the security of importing from a variety of countries to reduce risk, for energy-exporting countries like Kazakhstan, diversification of markets is important for security and economic growth stabilization. Since becoming independent, Kazakhstan has relied largely on pipelines through Russia to export its hydrocarbons. To diversify export routes, Kazakhstan has seen the development of the aforementioned BTC oil pipeline as a critical component to getting around using Russian pipelines, and thereby diversifying and expanding its export capability. The BTC oil pipeline is a dedicated pipeline system designed to transport up to one million barrels per day of crude oil from Baku in Azerbaijan, through Georgia, to a new marine terminal at Ceyhan in Turkey on the Mediterranean coast. From Ceyhan, the oil is transported by tankers to international markets. The $1,760 \mathrm{~km}$ pipeline became operational in early 2005 (European Bank for Reconstruction and Development 2002). Since 2013, Kazakhstan has transferred 50-60 thousand barrels of oil daily through the BTC pipeline (Gusseinov 2014).

The vast oil field Kashagan, near the Caspian Sea, is Kazakhstan's main oil production site. Kazakhstan produced about 82 million tons of oil in 2013, and one-third of it was exported via Russian pipelines. Kazakhstan's Oil and Gas Minister Uzakbay Karabalin said on April 7, 2014 that Kazakhstan's export potential via Russian pipelines was threatened, and that there was a need

\footnotetext{
2 "Proven" reserves are economically recoverable.

3 "Prospective" reserves suggest a potential for much greater production.
} 


\section{BTC Pipeline}

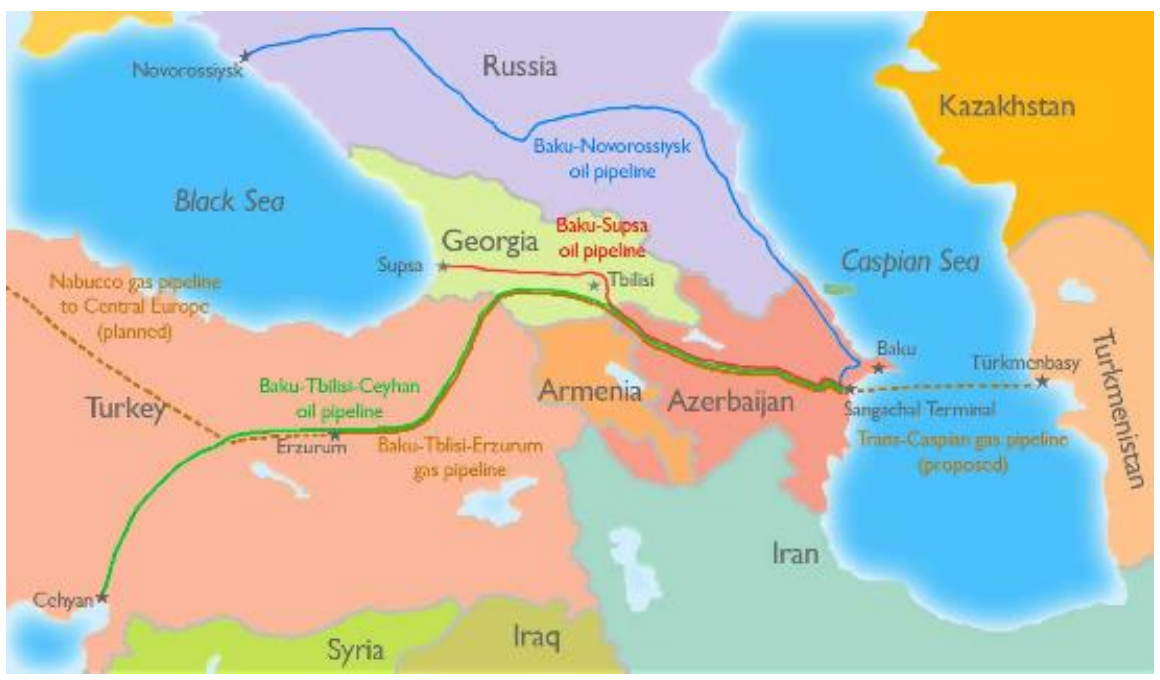

Source: http://za-gonzalez.livejournal.com/349361.html?thread=4753585

to improve alternative routes, by which he meant increasing the amount of oil that could be exported through the BTC (Jafarova 2014). He discussed enlarging Kazakhstan's Caspian Sea eastern shore port at Aktau, from which tankers transport oil across the Caspian to Baku, Azerbaijan, the terminus of the BTC pipeline, which would transport the oil to Europe. Aktau is currently undergoing massive expansion and renovation and could, according to Karabalin, ship up to 20 million tons of oil annually within a couple of years (Pannier 2014). Kazakhstan is also building up its tanker fleet, as is Turkmenistan, to increase the amount of oil shipped from Aktau to Baku (ibid.).

To facilitate this increase, an agreement between Kazakhstan and Azerbaijan to ship Kazakh oil through the BTC pipeline was renewed. Negotiations had been suspended over a pricing dispute in 2010, but the rising demand from Europe spurred the countries to make an agreement. In 2014, Kazakhstan was expected to export four million tons of oil through the BTC pipeline (Pannier 2014).

Kazakhstan's oil production has grown rapidly in recent years. According to the World Bank, however, Kazakhstan's real GDP growth slowed from 6 percent in 2013 to 3.9 percent during the first half of 2014, due to the decline in worldwide oil prices and the economic slowdown in Russia (World Bank 2015). Kazakhstan officials have hinted at increasing oil production to offset financial losses, despite pressure from the OPEC countries to restrain production. Increased production will require an increase in the transit of oil through pipelines. In late 2013, an agreement was signed between Kazakhstan and Azerbaijan for production to be raised, with the idea that in 2014, around 4.5 million tons of oil would be pumped from the Tengiz field (Gusseinov 2014). Three million tons of this amount will be transported through the BTC, and the rest will go by rail to the Georgian Kulevi terminal on the Black Sea (IA Novosti-Kazakhstan 2013).

The issue of Kazakhstan's dependence on the Russian pipeline system since independence has become especially acute since sanctions were placed on Russia due to the Crimean crisis. Western sanctions on Russia have limited Kazakhstan's ability to export oil through Russia (IA Novosti- 
Kazakhstan 2013). This development provides further incentive for Kazakhstan to increase its use of the BTC and other alternative routes.

\section{European investment in Kazakhstan energy}

The significant energy resources of Central Asia and the region's desire to diversify energy routes have caught the attention of the EU. Among the Central Asian countries, Kazakhstan is the top priority for energy cooperation because about $76 \%$ of crude oil goes to Europe (see graph below), and half of foreign investment in Kazakhstan is of European origin.

One example of this growing partnership is a preliminary agreement on an expanded partnership and cooperation between Kazakhstan and the European Union, concluded on January 20, 2015 in Brussels. This document shows that Europe is committed to stronger political and economic relations with Kazakhstan, which will increase the flow of trade, services, and investment between the two sides.

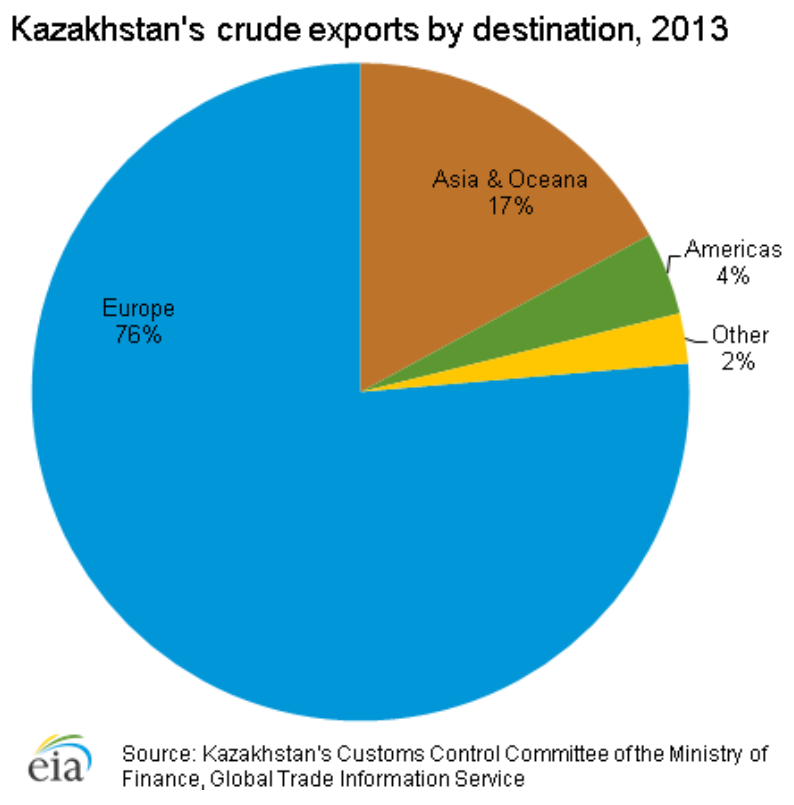

Source: US Energy Information Administration 2015

\section{Italy, the leading EU partner of Kazakhstan}

Italy, one of the EU member states, has been a leader in exchanges with Kazakhstan. Its geographic location makes it easy for hydrocarbons coming from the BTC pipeline terminus in Turkey and the Black Sea to enter its Mediterranean Sea ports. In the future, Italy's position as a key entry port for Central Asian hydrocarbons into Europe is likely to continue. For example, the Trans Adriatic 
pipeline (TAP), ${ }^{4}$ which will connect with the Southern Gas Corridor to bring Black Sea oil into Europe, will have its terminus in Italy. Of all of the Central Asian countries with which Italian energy companies have done business since the collapse of the Soviet Union in 1991, Kazakhstan, with the largest oil reserves in the region, is their most frequent partner.

The Ambassador of Kazakhstan in Italy, Elemesov, noted that:

Among other countries of 'old Europe,' the most active in Central Asia is Italy . . . Italy has developed the practical dimension of its policy in the Central Asian region in a framework of a Strategy for a New Partnership between the EU and Central Asia, which was initiated in 2007. According to the stated (designated) priorities, the focus of the foreign policy of Rome officially aims to develop bilateral and multilateral cooperation with Central Asian countries in various fields, including trade, cultural ties, cooperation on the level of public organizations, projects to promote democracy, and the rule of law. However, the strategic line of Italy in the region was built in the field of energy and security. According to the majority of Italian and European experts, the key economic and energy partner of Rome in Central Asia is Astana [Kazakhstan]. (Elemesov 2015, 46-49; author's translation)

The economic component takes a special place in the foreign policy of Kazakhstan. In this respect, the interests of the two countries meet, which allows for the development of bilateral relations. This economic cooperation has provided a foundation for the formation of other foreign policy areas between the two countries in recent years. Kursiv Research rated the countries that were the biggest trade partners of Kazakhstan at the end of 2013. The study found that Italy was Kazakhstan's third largest trade partner, behind only Kazakhstan's largest neighbors, Russia and China. Trade turnover between the two countries amounted to $\$ 16.22$ billion (Kursiv Research 2014).

Looking at oil exports alone, Kazakhstan's First Deputy Minister of Energy Karabalin reported that Kazakhstan exported 62.5 million tons of oil in 2014, 25\% of which was delivered to Italy, $17 \%$ to China, $13 \%$ to the Netherlands, $9 \%$ to France, and $7 \%$ to Austria. In 2015, Kazakh companies plan to increase oil production to as much as 80.5 million tons (Italiya 2015).

Currently, Italy-Kazakhstan trade is very one-sided and one-dimensional. $93.87 \%$ of ItalyKazakhstan trade is made up of Kazakhstan exports to Italy. Out of those exports, $99.37 \%$ of it is crude oil and crude oil products. The imports coming from Italy are primarily finished manufactured products, such as machinery, equipment, tools, and chemical industry products, including pharmaceuticals (Kursiv Research 2014).

Another important factor contributing to the promotion of trade and economic cooperation between the two countries, especially in the energy sector, was the coming to power of Matteo Renzi as Prime Minister of Italy on February 22, 2014. Renzi stressed the importance of Kazakhstan to Italy, noting that Kazakhstan "is of great importance from an economic point of view, but above all, from the energy" (Nakipova 2014; author's translation). The Italian company "Ente Nazionale Idrocarburi" (ENI) has been a major player in the energy sector in Kazakhstan since the first years of independence, and has been involved in the development of the Kashagan

\footnotetext{
${ }^{4}$ The Trans Adriatic Pipeline is a pipeline project to transport natural gas from the Caspian Sea (Azerbaijan), going from Greece via Albania and the Adriatic Sea to Italy and further into Western Europe. The construction of this project will be started in 2015 and is expected to begin operating in 2018.
} 


\begin{tabular}{|lllll|}
\hline \multicolumn{5}{|c|}{ Top 10 trading partners of the Republic of Kazakhstan in 2013 (\$USD billions) } \\
No. & Country & 2013 & 2012 & Changes \\
1 & Russia & 23.49 & 23.10 & $1.71 \%$ \\
2 & China & 22.53 & 21.67 & $3.94 \%$ \\
3 & Italy & 16.22 & 16.34 & $-0.75 \%$ \\
4 & Netherlands & 10.09 & 4.57 & $33.25 \%$ \\
5 & France & 6.19 & 6.29 & $-1.57 \%$ \\
6 & Switzerland & 4.45 & 5.14 & $-13.46 \%$ \\
7 & Austria & 4.36 & 5.23 & $-16.67 \%$ \\
8 & Ukraine & 4.28 & 5.31 & $-19.40 \%$ \\
9 & Turkey & 3.50 & 3.51 & $-0.48 \%$ \\
10 & Germany & 2.23 & 5.22 & $-38.07 \%$ \\
\hline
\end{tabular}

Agency of the Republic of Kazakhstan on Statistics (Kursiv Research 2014)

and Karachaganak oil fields. In the medium term, Italy has considered Kazakhstan to be a more reliable provider of oil than Azerbaijan. As Christiani (2012) notes,

In addition to the proven oil reserves of both countries, according to which Kazakhstan has $1.8 \%$ of the world's oil reserves, and Azerbaijan - only $0.4 \%$, it is generally accepted that Kazakhstan could be a more reliable partner for oil in the long term. In the first half of 2012, according to official data, the indicators of Azerbaijan's oil sector decreased by $7.1 \%$ and the associated exports declined by $8.2 \%$. Given these trends, the reliability of the oil industry in the medium term is a key element of political and economic calculations of Italy in the region.

The ongoing development of trade and economic relations between Kazakhstan and Italy has continued to grow. According to the Kazakhstan Statistics Agency, the 2010 bilateral trade amounted to $\$ 11.1$ billion, and in 2011 , this figure increased to $\$ 16.1$ billion. In 2012 , the volume of trade between the two countries reached a record of $\$ 16.4$ billion. Kazakh-Italian trade in the period from 1994 (\$103 million) to 2012 increased 159-fold (Elemesov 2015, 47). In recent times, major Italian businesses in Kazakhstan have focused mainly on the energy, raw materials, and construction sectors of Kazakhstan's economy. The leading Italian companies are "Eni," "Finmeccanica," and "Italcementi" (ibid.). Paolo Ghirelli, Chairman of the Chamber of Commerce and Industry of Italy - Kazakhstan, noted that "Kazakhstan has launched a multi-billion program of investments in the oil and gas industry and infrastructure and is the most dynamic and interesting market in Central Asia for Italian companies" (Ghirelli 2009, 8-9).

Italy was a leader in implementing the Energy Roadmap in Kazakhstan, an EU-Central Asian agreement adopted at the 2nd Ministerial Conference, which took place on 30 November 2006 (2nd Ministerial Conference 2006). The Energy Roadmap sets out a long-term action plan, 
including enhancing energy security by addressing the issues of energy export/import, diversification of supply, transit of energy, and demand management (ibid.). Further steps to strengthen cooperation between the EU and Kazakhstan were discussed at the event INOGATE as a successful energy cooperation programme: achievements in Kazakhstan and the way forward in 2014 on June 18, 2014. As was noted, "Kazakhstan has been and remains one of the key partners of the EU INOGATE, [and has] acted as beneficiary in 41 of the 69 projects of INOGATE" (Kazakhstan and EU 2014). The EU Ambassador Aurelia Bouchez stated that "Europe shares with Kazakhstan the conviction that our citizens need a secure supply of energy at internationally competitive prices" (ibid.).

\section{Italy as the largest importer of Kazakhstan's oil}

According to Kazakhstan's Customs Control Committee of the Ministry of Finance, the largest share of its exports was destined for Italy in 2012 (at about 355,000bbl/d. Other notable importers of Kazakhstan's liquid fuels included China, the Netherlands, France, and Austria (US Energy Information Administration 2013a). The key to Kazakhstan's continued growth in liquids production will be the development of its giant Tengiz, Karachaganak, and Kashagan fields.

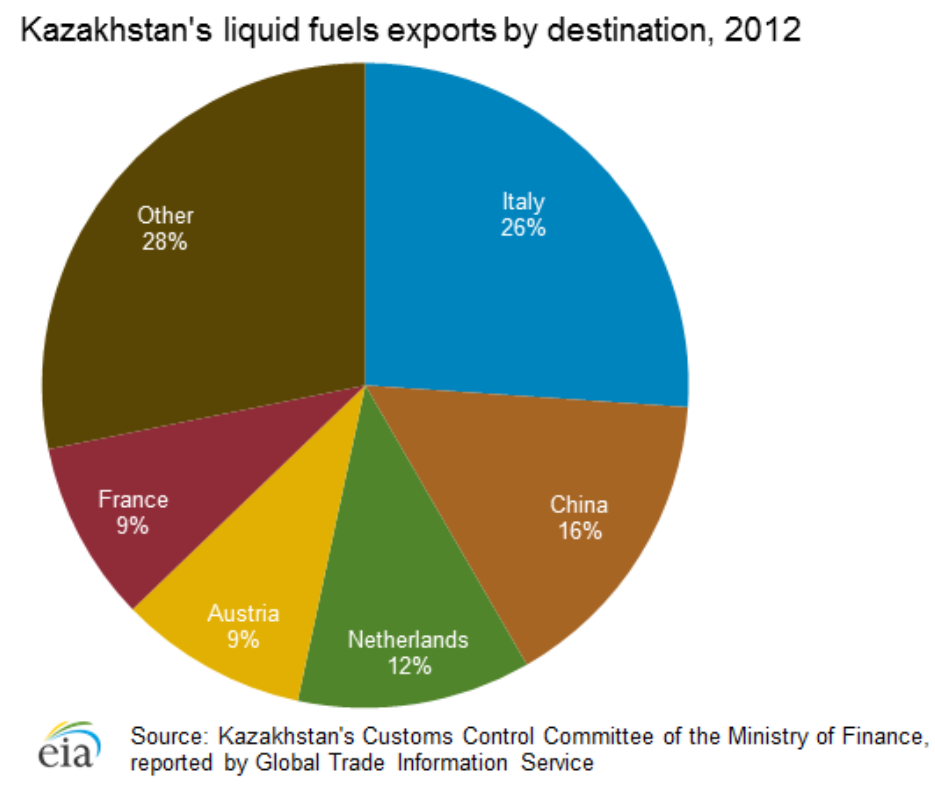

Since the early years of independence, Kazakhstan's oil reserves have been the basis for the development of bilateral cooperation with a number of countries, including Italy. One of the main and constant aims of Italian foreign policy is to guarantee the stability of its energy supplies. Around 63 Italian companies currently do business in Kazakhstan, including such major oil companies as the Eni consortium companies Agip KCO Atyrau and Agip Karachaganak BV. The

\footnotetext{
${ }^{5}$ INOGATE is a regional energy cooperation programme between the European Union and 11 Partner Countries in Eastern Europe, the Caucasus, and Central Asia.
} 
Agip companies have worked in the Kazakhstan market for over 20 years and started the development of such fields as Karachaganak and Kashagan (Kursiv Research 2014).

Kashagan, an uplifted reef in the subsalt Northern Caspian, was explored by Soviet geophysicists in the period from 1988 to 1991. Later studies by Western Geophysical Companies confirmed the Soviet findings. The three primary masses were eventually named Kashagan East, West, and Southwest (Mineraly 2014). On June 30, 2000, the "Vostok-1" well in Kashagan East was the first to produce oil. Production at the West and Southwest fields began in 2001 and 2003 respectively. The proved reserves amounted to about 35 billion barrels.

However, despite possessing vast oil reserves, extraction at the Kashagan field is complicated by climatic conditions. Kashagan oil lies at a depth of 4,200 meters below the sea floor and is under high pressure. The oil deposit is located in the shallow part of the Northern Caspian, due to the low level of salinity (mineralization) caused by the influx of fresh water from the Volga. Furthermore, the temperature in winter drops to as low as $-40^{\circ} \mathrm{C}$, resulting in the North Caspian Sea being covered in ice for about 5 months of the year. (Mendebayev 2014).

Kazakhstan could not independently develop a deposit with such complex climatic and geological conditions. In 1997, Kazakhstan signed the "Agreement on Production-Sharing in the North Caspian Sea," a 40-year treaty with the consortium OKIOC (formerly known as Agip KCO). In 1998, the consortium OKIOC included such companies as: TotalFinaElf, Statoil, BP Amaco, Bc Plc, Royal Dutch/Shell, Exxon Mobil, Philips Petroleum, and Inpex. In February 2001, the operator of the OKIOC became the company Agip KKO (Kokovinets 2001).

In January 2008, the Kashagan project was transferred from Agip KKO to the new operating company, North Caspian Operating Company (NCOC) (Nomad.su 2008). The aforementioned agreement on production-sharing is made up of 7 companies consisting of the Kazakh state-run oil company KazMunaiGas (16.88\%), AgipKCO (Eni) (16.807\%), Royal Dutch Shell (16.807\%), Total S.A. (16.807\%), ExxonMobil (16.807\%), China National Petroleum Corporation (8.333\%, which was acquired from ConocoPhillips for $\$ 5$ bn in 2013), and Inpex (7.563\%). Eni is responsible for Phase I of the field's development, while Shell is responsible for production operations (Nomad.su 2008).

Nevertheless, according to Kazakhstan's Oil Minister Uzakbai Karabalin, "the North Caspian Operating Company is undergoing changes, a new managing system is being created, and the new operator, which will include three organizations: Agip, NCOC (North Caspian Operating Company), and NCPOC (North Caspian Production Operations Company, which is a joint venture between Shell Kazakhstan Development B.V. and KMG Kashagan B.V. that sees both sides hold equal participation shares 50/50 will comprise specialists employed with member companies of the consortium" (Tengrinews June 18, 2014a; author's translation). He explained the change, noting that "both subcontractors and the Ministry were dissatisfied with the system in place up to now. It has been too costly; decision-making has taken a lot of time due to the complexity of the hierarchy" (ibid.; author's translation). A gas leak led to a suspension of production in October 2013, which resulted in a 0.5\% decrease in GDP in 2014. Vice Minister of Oil and Gas Magzum Myrzagaliyev said that the giant Kashagan oilfield should resume commercial production in late 2015 (ibid.). 
On June 11, 2014, in a meeting between Kazakhstan's president Nursultan Nazarbayev and the CEO of Italian Eni Claudio Descalzi, President Nazarbayev expressed concern about the development of the Kashagan oil and gas field, which has been hindered by multiple delays and cost overruns throughout its existence. Nevertheless, they discussed the expansion of oil transportation networks in Kazakhstan, as well as Eni's role in other oil and gas projects in Kazakhstan (Tengrinews June 13, 2014). After Nazabayev's meeting, the members of the NCOC signed a memorandum of understanding with the Government of Kazakhstan regarding further development and exploitation of the Kashagan project, which also included an agreement on Kazakhstan's participation in the project and the field's production capabilities (Tengrinews June 18, 2014b).

As we can see, the gas leak at the Kashagan field had no effect on bilateral relations; in fact, it deepened the relationship. The oil exports from Kazakhstan to Italy between January and May 2014 increased by $21.5 \%$ in comparison with the same period in 2013 (Kapital.kz 2014). In July, the figures were:

Italy - 12.6 million tons equating $\$ 10.3$ billion

China -4.4 million tons equating $\$ 3.6$ billion

Netherlands -5.2 million equating $\$ 4.2$ billion (I-News. kz 2014).

Italy's interests in Kazakhstan are not restricted to the stable supply of energy resources, as there is also a keen interest in integrating with other sectors. Italy intends to build a shipyard in the Caspian Sea. The contract for the establishment of the joint oil venture was signed by Italy's Eni and the Kazakh company KazMunaiGas, and ensured that $50 \%$ of the shares will be owned by each party (Mining News.kz 2014). The consortium Eni is the largest integrated company in Italy, and its activities are not limited to the oil and gas industry. Eni together with KazMunaiGas are building a shipyard in the Kuryk port (IA Novosti-Kazakhstan 2012). This shipyard has the potential to play a significant role in the promotion of Kashagan's oil exports via the BTC pipeline to European markets. Thus, the role of Italy in the development of Kazakhstan-EU cooperation is enormous, due to its possible huge contribution to the transportation of Kashagan oil along the BTC pipeline.

According to the US Energy Information Administration (EIA), Kazakhstan is aiming to utilize foreign investment to construct the Kazakhstan-Caspian Transportation System (KCTS). The suggested plan is to export oil, primarily produced at Kashagan and Tengiz, to international markets. Proposals would see the oil first transported through a new pipeline east of the Caspian to a terminal at Kuryk, and then shipped to Baku, where it would enter the BTC pipeline. Initially, KCTS is expected to supply 300,000 barrels per day to global markets through the BTC; however, it is estimated that this figure will gradually increase to 800,000 barrels per day (US Energy Information Administration 2013c).

Kazakhstan intends to expand its cooperation with Italy as part of its policy of industrial development through attracting high technologies. Kazakhstan chose Italy as the main partner for oil development of Kashagan due to its leading position in foreign direct investment (FDI), as well as its considerable political and economic weight within the European Union. Italy's geographical location also plays an important role in the distribution of oil to other European countries, so in this respect, Italy is considered to be the representative country of the European Union. 


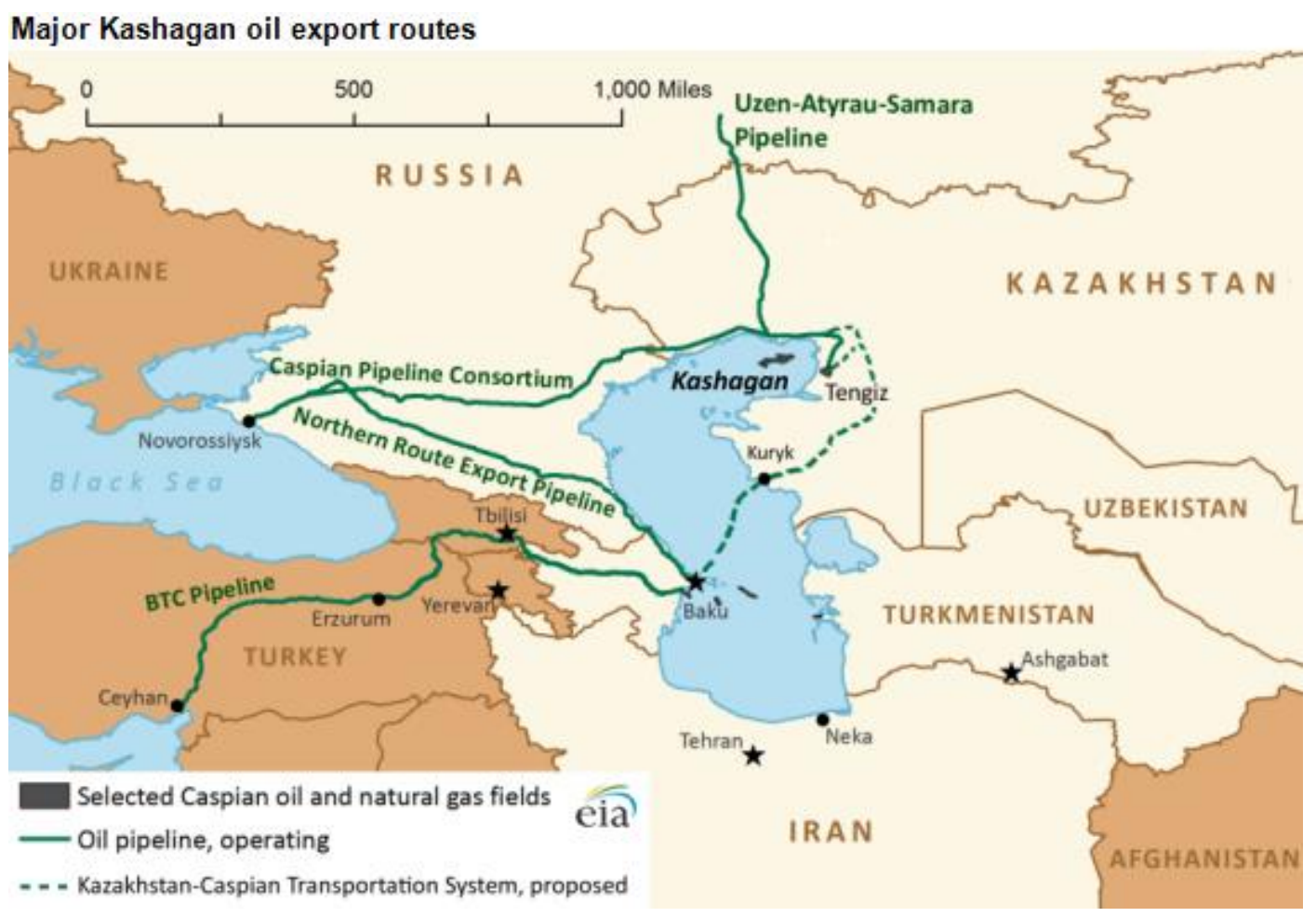

Source: US Energy Information Administration (2013)

Nonetheless, while Kazakhstan has achieved substantial results in attracting foreign investments into priority sectors, FDI and exports have still been highly concentrated (more than 70\%) in natural resources (Organization for Economic Cooperation and Development 2012). Thus, Kazakhstan decided to create the Industrial and Development Program in order to diversify FDI into primary sectors and thereby become more advanced in the field of technological development; this will be discussed in the next section.

\section{Kazakhstan's goal to attract investments and new technologies}

Kazakhstan's intentions for further cooperation, as well as to attract investment and develop new technologies, were in evidence at the World Petroleum Congress, which was held in Moscow in June 2014. Investors took note when a representative from the oil industry, Damiano Ratti, noted that "special interest arose due to the fact that the government plans to compensate foreign investors by up to 30\% of capital costs once in operation" (Prikaspiyskaya kommuna 2014; author's translation). National plans to draw in investments to non-oil-related sectors of the Kazakhstani economy, during the 2015-2020 period, aim to attract 81 companies that will contribute to the development of alternative forms of energy in Kazakhstan (Ministerstvo Industrii i novykh tekhnologiy, 2011).

An important factor in the development of Kazakh-Italian relations could be the Eurasian Economic Union. At a conference on Investment, legal and tax climate in the countries of the Customs Union held in Rome on June 20, 2014, the president of the Chamber of Commerce of 
Rome, Giancarlo Cremonesi, noted that "the creation of the Eurasian Union is a great chance for companies from our country who want to work and develop business in the region" (Evraziyskii kommunikatsionnyi tsentr 2014; author's translation). Italy, as a country with interests in the issue and in the region (Italy imports $85 \%$ of its energy resources), could also assist in helping to strengthen cooperation regarding energy resources between Kazakhstan and the EU. Given that Italy took over the EU presidency on July 1, 2014, it has the potential to play an even greater role in consolidating ties between Kazakhstan and the EU. As Sandro Gozi, State Secretary of the Council of Ministers responsible for European policy, said in an interview with Itar-Tass,

We do not intend to assume a decisive role, but want to turn Europe towards new political priorities through the introduction of more effective methods of management and decision-making. In our opinion, the renovation of Europe, which is a topic that is greatly discussed in all countries, requires a change in approach. We hope to put new boundaries in place for the European leadership, set five year goals, and to help Europe solve them. (Zabrodina 2014; author's translation)

At a joint press briefing on 12 September 2014, Alexey Volkov, Deputy Minister of Foreign Affairs of Kazakhstan, noted that "we have completed negotiations on a new agreement on the expanded partnership and cooperation between Kazakhstan and the EU. We hope that this document will promote our relationship and open a corridor for interaction, and create greater opportunities to access innovative projects and European technologies" (Predstavitel'stvo ES v Kazakshtane 2014; author's translation). As noted by Gunnar Wiegand, " "...we have an agreement that will allow us to create a new and better basis for our relations and further development. In the new agreement, we have significantly increased the area of cooperation, which will now cover 29 areas, including such important areas as the economy, trade, and investment... The scope of our cooperation significantly expands in the field of the economy, as European companies are the largest investors in Kazakhstan" ibid;; author's translation). The expansion of cooperation between Kazakhstan and the EU will undoubtedly have a positive impact on the expansion of cooperation between Kazakhstan and Italy, which cooperates not only on energy, trade, and economy, but also on such areas as research and innovation, education, transport, and communications, among others.

\section{Conclusion}

Despite its vast natural resources, the landlocked geographical position of Kazakhstan makes it difficult to transport natural resources. Just as energy-importing countries value the security of importing from a variety of countries to reduce risk, for energy-exporting countries like Kazakhstan, diversification of markets is important for security and economic growth stabilization. Since independence, Kazakhstan has been largely dependent on pipelines through Russia to export its hydrocarbons. To diversify export routes, Kazakhstan has seen the development of the BTC oil pipeline as a critical alternative. Kazakhstan can now diversify its oil pipeline routes through utilizing tankers shipping to Azerbaijan. Nonetheless, the volume of oil that can be transmitted through tankers is limited.

\footnotetext{
${ }^{6}$ Director of the Department for Russia, Eastern Partnership of Central Asia, Regional Cooperation and the OSCE, European External Action Service
} 
Italy, one of the EU member states, has been a leader both in efforts to deal with the recent economic crisis, and in exchanges with Kazakhstan. Italy, as the largest importer of Kazakhstan's oil, could use Kazakhstan as a market for its services, as well as help Kazakhstan diversify its routes by providing a destination for Kashagan oil through the BTC pipeline. It holds a highly important geographic location as a link to the rest of Europe for hydrocarbons coming through the BTC pipeline terminus in Turkey and the Black Sea to ports on the Mediterranean Sea. Moreover, Italy has contributed to the development of Kazakhstan-EU energy cooperation through adopting a more proactive foreign policy in the EU vis-à-vis Kazakhstan.

These interests are mutually beneficial for Italy and other EU countries, especially after the Crimea incident, which made EU countries more aware of their dependency on Russian energy. In order to reduce their reliance on Russian energy resources, the EU countries must also open new pipeline routes. Kazakhstan's hydrocarbon resources have the potential to help alleviate Europe's energy security concerns. Kazakhstan is a major oil producer with potentially vast untapped hydrocarbon reserves.

Kazakhstan intends to expand its cooperation with Italy as a part of its policy of industrial development through attracting investments in high technologies. While Kazakhstan has achieved substantial results in attracting foreign investments into priority sectors, FDI and exports have still been highly concentrated in natural resources. Against this backdrop, Kazakhstan decided to create the Industrial and Development Program in order to diversify the FDI in the renewable energy sector, and, through doing so, become more advanced with regards to technological development. Both sides thus have mutually beneficial interests. Kazakhstan expects to reinforce its cooperation with Italy in the energy field not only in relation to energy security, but also in the acquisition of new and necessary technologies. 


\section{ACKNOWLEDGEMENTS}

The author gratefully acknowledges the in-depth analysis and helpful comments from two anonymous reviewers and Dara Marcus and Marcel Sangsari of the RERA editorial team. The author would also like to express her deepest gratitude to Professor Andrew Reed Hall, who has made a significant contribution to improving the paper by providing kind help on this article. Last, but not least, the author would like to thank her colleague Zhannah Voukitchevitch for invaluable suggestions and comments, and her colleague Hiro Hayashi for proofreading the article. 


\section{REFERENCES}

2nd Ministerial Conference. 2006. Enhancing energy co-operation between the EU, the Littoral States of the Black and Caspian Seas and their neighboring countries. (2006). Retrieved October 17, 2014, from Energy Portal: INOGATE.

http://web.inogate.org/pages/5?lang=en

Ashirova, Azhar, Dinara Urazova, and Tatyana Kuzmina. 2014. "Transition to new Kashagan operator started in May: NCOC," Tengri News, June 18, 2014a. Retrieved July 13, 2014. http://en.tengrinews.kz/companies/Transition-to-new-Kashagan-operator-started-in-MayNCOC-254236/

Ayvazyan, D. 2013. "The Hydrocarbon Potential of the Caspian Region: Assessments on Regional and International Levels." Mirovoi biznes $i$ politicheskaya vlast'. Retrieved from http://www.intertrends.ru/thirty-third/Biznes.pdf

Belkin, P. 2008. "The European Union's Energy Security Challenges." CRS Report RL 33636. Congressional Research Service. Retrieved March 13, 2015. http://fas.org/sgp/crs/row/RL33636.pdf

Christiani, Dario. 2012. “Italiya bol'she zainteresovana v Kazakhstane, a ne Azerbaijane.” August 8; Jamestown, August 7. Retrieved March 12, 2015. http://inozpress.kg/news/view/id/36729

Duffield, John. 2010. "Energy and Security.” The International Studies Encyclopedia. Ed. Robert A. Denemark. Blackwell Publishing.

Egemen Kazakhstan. 2011. "O strategicheskom plane Ministerstva nefti i gaza RK na 2011-2015 gody." April 15. Retrieved October 13, 2014. http://primeminister.kz/page/article_item-109

Elemesov, A. 2015. “O strategicheskikh podhodakh Italii v Tsentral'noi Azii.” Kazakshtan i Mirovoe Soobshestvo.

European Bank for Reconstruction and Development. 2002. BTC Project ESIA. http://www.ebrd.com/pages/project/eia/esia_geo.pdf

Evraziyskii kommunikatsionnyi tsentr. 2014. “Zachem ital'yantsam Evraziya? Zhdat' li ital'yanskim kompaniyam priklyuchenii v EAES.” Retrieved October 14, 2014. http://eurasiancenter.ru/perspective/20140625/1003559503.html

Ghirelli, Paolo. "The outlook for Italian General Contractors in Kazakhstan: Italian algorithm of the Oil Business in Kazakhstan.” Petroleum, no.5 (October 2009).

Gusseinov, K. 2014. “Tengizskaya neft' idet po BTD.” Retrieved October 16, 2014. http://www.neftegaz.kz/kazaxstanskie-novosti/tengizskaya-neft-idet-po-btd.html

IA Novosti-Kazakhstan. 2013. 'Kazakhstan s 2014 goda ezhegodno budet eksportirovat' 4 milliona tonn nefti cherez Azerbaidjan.” 08 November 2013. Retrieved October 16, 2014. http://www.newskaz.ru/economy/20131108/5765903.html 
2012. "Nazarbayev oznakomilsya s hodom realizatsii proektov KMG i Eni na zapade Kazakhstana.” 02 October 2012. Retrieved October 13, 2014. http://newskaz.ru/economy/20121002/4049671.html

I-News.kz. 2014. "Pochti 30\% vsego eksporta nefti iz Kazakhstana prihoditsya na Italiyu." 05 September 2014. Retrieved October 12, 2014. http://i-news.kz/news/2014/09/05/7709450 pochti_30_vsego_eksporta_nefti_iz_kazahs.html

International Energy Agency. What is energy security? Retrieved March 15, 2015. http://www.iea.org/topics/energysecurity/subtopics/whatisenergysecurity/

"Italiya, Kitai i Niderlandy - glavnye pokupateli kazakhstanskoi nefti." 25 February, 2015. Retrieved March 12, 2015. http://kzinform.com/ru/news/20150225/39968.html

"Italiya uvelichila import Kazakhstanskoy nefti na 21.5\% (dannye za yanvar'-may 2014 goda)." Kapital.kz, 09 July 2014. Retrieved October 12, 2014. http://kapital.kz/economic/31539/italiya-uvelichila-import-kazahstanskoj-nefti-na-21-5.html

Jafarova, Aynur. 2014. "Sanctions on Russia to have trickle down effect on Central Asia: expert." Azernews, 11 April. Retrieved March 12, 2015. http://www.azernews.az/analysis/65984.html

Kamalova, Gyuzel and Tatyana Kuzmina. 2014. "Consortium and Kazakh Government agree on stages of Kashagan development.” Tengrinews June 18, 2014b. Retrieved July 13, 2014. http://en.tengrinews.kz/politics_sub/Consortium-and-Kazakh-government-agree-on-stagesof-Kashagan-development-254234/

Kassenova, N. 2011. "EU-Central Asian bilateral cooperation.” In A. Warkotsch (Ed.), The European Union and Central Asia: Routledge.

“Kazakhstan and EU renew efforts for energy cooperation.” 2014. Kazakhstan, Astana. 19 June 2014. Retrieved October 17, 2014. http://inogate-tag.org/inogate/news.php?lang=en

Kokovinets, L. 2001. “Operatorom OKIOC stala ital'yanskaya kompaniya Agip.” Retrieved October 12, 2014. http://www.kase.kz/news/show/93517

Konyrova, K. 2013. "Kaspiyskii region budet odnim iz klyuchevykh regionov mirovogo neftegazovogo rynka, schitayut eksperty.” Panorama. (21.06.2013). Retrieved October 13, 2014. http://www.nomad.su/?a=3-201306210036

Kulmagambetov, R. 2013. "Perspektivy kaspiyskogo shel'fa." Kazakhstanskaya pravda. Retrieved October 13, 2014. http://www.nomad.su/?a=3-201306210036

Kursiv Research. 2014. "Krupneyshie torgovie partnery RK po itogam 2013 goda." Kursiv.kz. (03.03.2014). Retrieved October 13, 2014. http://www.kursiv.kz/news/details/top_ratings/ Krupnejshie-torgovye-partnery-RK-po-itogam-2013g/

Laumulin, M. 2000. Kazakhstan v sovremennykh mezhdunarodnykh otnosheniyakh: bezopasnost', geopolitika, politologia. Almaty. 
Mendebayev, T. 2014. "Kashaganskaya neft'. Voprosy, voprosy..." Oil and Gas Journal Russia. Retrieved October 14, 2014. http://ogjrussia.com/uploads/images/Articles/Sept14_article1/18-21.pdf

Mineraly. 2014. "Kashaganskoe neftegazovoe mestorozhdenie." Catalog mineralov.ru. Retrieved October 14, 2014. http://www.catalogmineralov.ru/deposit/kashagan/

Mining News.kz. 2014. "Italiya i Kazakhstan sozdadut sovmestnoe neftyanoe predpriyatie." (16.06.2014). Retrieved October 12, 2014. http://miningnews.kz/kazakhstan/466-italiya-ikazahstan-sozdadut-sovmestnoe-neftyanoe-predpriyatie.html

Ministerstvo Industrii i novykh tekhnologiy. 2011. "Natsional'nii plan po privlecheniyu investitsii v nesyr'evoi sector ekonomiki Kazakhstana.” Astana, October. Retrieved October 14, 2014. http://www.analitika.kz/images/Gulden/nacplan.pdf

Musabekova, A. 2010. Kratkii obzor neftedobyvayushchei otrasli Kazakhstana. Retrieved October 11, 2014.

http://rfcaratings.kz/uploads/kratkiy_odzor_neftedobyvaiushei_otraski_rk_092010.pdf

Nakipova, Zhanna. 2014. "Italiya nuzhdaetsya v takikh partnerakh, kak Kazakhstan." BNews.kz. (12.06.2014). Retrieved March 13, 2015. http://bnews.kz/ru/news/post/210717/

Nomad.su. 2008. "Peredacha funktsii operatora proekta Kashagan ot Agip KCO k novoi operatsionnoi kompanii North Caspian Operating Company sostoitsya v yanvare 2009 goda." (04.11.2008). Retrieved October 12, 2014. http://www.nomad.su/?a=4-200811040027

Organization for Economic Cooperation and Development. 2012. Foreign Direct Investment in Kazakhstan. OECD Investment Policy Reviews: Kazakhstan 2012. Retrieved October 13, 2014. http://www.oecd-ilibrary.org/docserver/download/2012051 ec004.pdf?expires $=1405231555 \&$ id $=$ id\&accname $=$ oid008387\& checksum $=233$ BA5ACD0610DE33E1138B038628925

Özgür Özdamar. 2010. "Energy, Security, and Foreign Policy." The International Studies Encyclopedia. Ed. Robert A. Denemark. Blackwell Publishing.

Pannier, B. 2014. "Sanctions on Russia Open Southern Corridor." Retrieved July 13, 2014. http://www.rferl.org/content/gas-ukraine-pipeline-southern-corridor-russia-central-asiacaucasus/25327333.html

Predstavitel'stvo ES v Kazakshtane. 2014. "Sovmestnii brifing po itogam 8-go raunda peregovorov o rasshirennom partnerstve i sotrudnichestve mezhdu ES i Kazakhstanom.” (12.09.2014). Retrieved October 14, 2014. http://eeas.europa.eu/delegations/kazakhstan/documents/press corner/2014/transcript_12_sep_2014_ru.pdf

Prikaspiyskaya kommuna. 2014. "Vsemirnyi neftyanoi kongress: pozitsii Kazakhstana krepnut." (21.06.2014). Retrieved October 14, 2014. http://pricom.kz/?p=32746

Tengrinews. 2014. "New Operator for Kashagan to be launched by September 2014." Retrieved July 13, 2014. http://en.tengrinews.kz/markets/New-operator-for-Kashagan-to-be-launched-bySeptember-2014-253797/ 
Ukaz, P. 2003. “Ukaz Prezidenta RK ot 16.05. 2003 №1095 o gosudarstvennoi programme osvoeniya kazakhstanskogo sektora kaspiyskogo morya." Retrieved October 11, 2014. http://kazakhstan.news-city.info/docs/sistemsx/dok_ieqpyo/

Urazova, Dinara and Tatyana Kuzmina. 2014. "Nazarbayev worried about Kashagan," Tengrinews June 13. Retrieved July 13, 2014.

http://en.tengrinews.kz/politics_sub/Nazarbayev-worried-about-Kashagan-254153/

US Energy Information Administration. 2013a. Kazakhstan, Independent Statistics and Analysis. Retrieved July 8, 2014.

http://www.eia.gov/countries/analysisbriefs/Kazakhstan/kazakhstan.pdf

—. 2013b. Saudi Arabia, Independent Statistics and Analysis. Retrieved July 13, 2014. http://www.eia.gov/countries/country-data.cfm?fips $=$ sa

—. 2013c. "Kazakshtan consortium achieves first oil production from Kashagan field." (19.09.2013). Retrieved March 13, 2015.

http://www.eia.gov/todayinenergy/detail.cfm?id=13011

- 2015. Overview of Kazakhstan. (14.01.2015). Retrieved March 13, 2015. http://www.eia.gov/countries/cab.cfm?fips=kz

Weitz, R. 2014. "EU Seeks Energy Security Solutions to Russian Gas Challenge.” Retrieved October 14, 2014, from World Politics Review.

http://www.worldpoliticsreview.com/articles/13831/eu-seeks-energy-security-solutions-torussian-gas-challenge

Wolfers, A. 1952. “ 'National Security' as an Ambiguous Symbol.” Political Science Quarterly, Vol.67, No. 4, 481-502. The Academy of Political Science. Retrieved March 14, 2015. http://www.jstor.org/stable/2145138

World Bank. 2015. Kazakhstan Overview. Retrieved March 13, 2015. http://www.worldbank.org/en/country/kazakhstan/overview

Zabrodina, E. 2014. Predsedatel'stvo Italii v ES pridast novii impul's otnosheniyam s RF. Rossiyaskaya gazeta RG.RU. (01.07.2014). Retrieved October 14, 2014.

http://www.rg.ru/2014/07/01/predsedatelstvo-site-anons.html 
Published by the Centre for European Studies at Carleton University, Ottawa, Canada Available online at: journals.carleton.ca/rera/index.php/rera

RERA is an electronic academic peer-reviewed journal that publishes graduate, post-graduate, and young scholarly works. Topics relate to the European Union, its Member States, the former Soviet Union, and Central and Eastern Europe. The journal is a joint project supported by the CanadaEurope Transatlantic Dialogue - a cross-Canada research network supported by the Social Sciences and Humanities Research Council of Canada (SSHRC) — along with the Institute of European, Russian and Eurasian Studies (Carleton University) and its associated research unit, the Centre for European Studies.

RERA aims to provide an accessible forum for research, to promote high standards of research and scholarship, and to foster communication among young scholars.

\section{Contact:}

Carleton University

The Centre for European Studies

1103 Dunton Tower

1125 Colonel By Drive

Ottawa, ON K1S 5B6

Canada

Tel: +01 613 520-2600 ext. 3117; E-mail: rera-journal@ carleton.ca

\section{Creative Commons License}

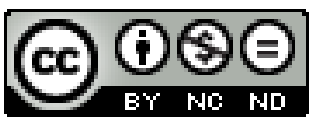

creativecommons.org/licenses/by-nc-nd/3.0

This Working Paper is licensed under a Creative Commons Attribution-Non-CommercialNo Derivs 3.0 Unported License (CC BY-NC-ND 3.0).

Articles appearing in this publication may be freely quoted and reproduced, provided the source is acknowledged. No use of this publication may be made for resale or other commercial purposes.

ISSN: $1718-4835$

(C) 2015 The Author 